\title{
Elevated Acetoacetate and Monocyte Chemotactic Protein-1 Levels in Cord Blood of Infants of Diabetic Mothers
}

\author{
Dalibor Kurepa Arun K. Pramanik Venkatakrishna Kakkilaya Gloria Caldito \\ Lynn J. Groome Joseph A. Bocchini Sushil K. Jain \\ Departments of Pediatrics and Obstetrics and Gynecology, Louisiana State University Health Sciences Center, \\ Shreveport, La., USA
}

\section{Key Words \\ Infant of diabetic mother - Oxidative stress - Monocyte chemotactic protein- $1 \cdot$ Acetoacetate $\cdot$ Hyperketonemia}

\begin{abstract}
Background: Infants of diabetic mothers (IDMs) are at increased risk for metabolic complications. Type 1 and some type 2 diabetic patients have elevated levels of the ketone bodies acetoacetate (AA) and $\beta$-hydroxybutyrate (BHB). $\mathbf{O b}$ jective: The aim of this study was to examine how hyperketonemia in diabetic mothers affects markers of inflammation and oxidative stress in their offspring. Methods: Blood was obtained from 23 diabetic mothers and 13 healthy mothers and their infants' umbilical cords at delivery. Interleukin-8, monocyte chemotactic protein-1 (MCP-1) and protein carbonyl (protein oxidation) levels were determined by ELISA. U937 human monocyte cell culture was used to examine the effect of $A A$ and $B H B$ on secretion of MCP-1. Results: There was a significant increase in the levels of $A A$ in cord blood of IDMs compared with cord blood of infants of healthy mothers. A significant increase in the levels of protein oxidation $(p<0.05)$ and MCP-1 levels $(p<0.05)$ was observed in the cord blood of IDMs. The level of MCP-1 correlated significantly $(r=0.51, p=0.01)$ with the concentration
\end{abstract}

of $A A$ in the IDMs. In further experiments with cultured monocytes treated with exogenous AA (0-4 mM), a significant increase in MCP-1 secretion was observed in AA- but not BHB-treated monocytes. Conclusion: Blood levels of AA and MCP-1 are elevated in IDMs, which may contribute to the development of the metabolic complications seen in IDMs.

Copyright $\odot 2012$ S. Karger AG, Basel

\section{Introduction}

Maternal hyperglycemia leads to elevated blood glucose levels in the fetus and a metabolically abnormal fetal milieu. This may result in birth defects, spontaneous abortions, macrosomia, asphyxia, respiratory distress syndrome and other metabolic complications [1-3]. Infants of diabetic mothers (IDMs) may be at an increased risk for developing diabetes and/or obesity later in life [1]. Controlling hyperglycemia during pregnancy reduces these complications in their offspring. In addition to hyperglycemia, hyperketonemia also occurs in type 1 and some type 2 diabetic patients [4]. Hyperketonemia can cause increased circulating levels of proinflammatory cytokines [5-7]. Vascular inflammation plays an important role in the development of many complications associat-

\section{KARGER \\ Fax +4161306 1234 \\ E-Mail karger@karger.ch}

www.karger.com
(C) 2012 S. Karger AG, Basel

$1661-7800 / 12 / 1023-0163 \$ 38.00 / 0$

Accessible online at:

www.karger.com/neo
Dr. Sushil K. Jain

Department of Pediatrics, Louisiana State University Health Sciences Center 1501 Kings Highway

Shreveport, LA 71130 (USA)

Tel. +1 318675 6086, E-Mail sjain@ lsuhsc.edu 
ed with diabetes mellitus during pregnancy and in the newborn period $[8,9]$. Even though ketonemia is associated with markers of inflammation in adult diabetic patients [5-7], the effect of ketonemia on the inflammatory markers in IDMs is unknown. Dahlgren et al. [10] reported that exposure of animals to cytokines prenatally in utero can induce gender-specific programming of neuroendocrine regulation with subsequent sequelae in adult life. In another study, ketonemia during pregnancy was associated with a lower intelligence quotient in children [11]. Ketone bodies are increased in maternal and fetal plasma of streptozotocin-treated diabetic pregnant ewes [12]. However, no study has examined if the cord blood of IDMs has elevated ketone levels. The objective of this study was to examine whether ketone levels are elevated in IDMs and the possible effects of hyperketonemia on proinflammatory cytokines and oxidative stress markers. This study measured ketone blood levels [acetoacetate (AA), $\beta$-hydroxybutyrate (BHB)], the levels of inflammatory markers [interleukin (IL)-8, monocyte chemotactic protein-1 (MCP-1)] and protein oxidation in diabetic mothers and healthy mothers (controls) as well as in the blood from umbilical cords of their respective infants at the time of delivery.

\section{Methods}

\section{Subjects}

The study was approved by the Louisiana State Health Sciences Center-Shreveport Institutional Review Board. Recruitment began in November 2008 and concluded in April 2010. Written informed consent was obtained from all study subjects. Subjects were divided into 2 groups, namely pregnant women with diabetes mellitus (study group, $\mathrm{n}=23$ ) and healthy nondiabetic pregnant women (control group, $\mathrm{n}=13$ ). The study group consisted of pregnant women with type 1 diabetes $(\mathrm{n}=$ $12)$, type 2 diabetes $(n=3)$ and gestational diabetes $(n=8)$. All the study group patients showed ketonemia. Data forms were completed for all patients. They included information on the following: age, type of diabetes, complications during any previous pregnancy, medications, substance abuse, chorioamnionitis, premature rupture of membranes, meconium, mode of delivery, gestational age, infants' Apgar score at $5 \mathrm{~min}$ and infants' complications at birth. Immediately prior to delivery, $10 \mathrm{ml}$ of venous blood was drawn from all mothers, and the umbilical vein of the placenta after delivery. The sample was divided into three aliquots; $2 \mathrm{ml}$ was used for the glycated hemoglobin $\left(\mathrm{HbA}_{1 \mathrm{c}}\right)$ assay, $2 \mathrm{ml}$ was used for the fructosamine measurements in the mother's blood, and the remaining 6-ml aliquot was centrifuged $(2,500 \mathrm{rpm}$ for $20 \mathrm{~min})$, and the plasma was recovered and frozen at $-80^{\circ} \mathrm{C}$. Immediately after delivery of the placenta, $6 \mathrm{ml}$ of cord blood was drawn from the umbilical vein and centrifuged, and plasma was frozen at $-80^{\circ} \mathrm{C}$.
Human Promonocytic Cell Line and Treatment with AA and $\mathrm{BHB}$

The U937 monocytic cell line was obtained from American Type Culture Collection (Manassas, Va., USA). These cells were maintained at $37^{\circ} \mathrm{C}$ in RPMI 1640 medium containing $7 \mathrm{mM}$ glucose, $10 \%(\mathrm{v} / \mathrm{v})$ heat-inactivated fetal bovine serum, $100 \mathrm{U} / \mathrm{ml}$ penicillin, $100 \mu \mathrm{g} / \mathrm{ml}$ streptomycin, $12 \mathrm{~mm}$ sodium carbonate, 12 $\mathrm{mM}$ HEPES and $2 \mathrm{mM}$ glutamine in a humidified atmosphere containing $5 \%(\mathrm{v} / \mathrm{v}) \mathrm{CO}_{2}$ and air. Cells were washed once in plain RPMI 1640 before suspension in fresh medium containing serum and other supplements $[5,6]$. The U937 cells $(500,000$ cells/ml) were treated with normal glucose $(7 \mathrm{mM})$ without and with AA or BHB (0-4 mM). For cytokine secretion studies, cells were stimulated with lipopolysaccharide (LPS; $2 \mu \mathrm{g} / \mathrm{ml}$ ) at $37^{\circ} \mathrm{C}$ for $24 \mathrm{~h}$. Values obtained with cells incubated with LPS alone were considered controls. All experiments were repeated 4 times.

\section{$H b A_{1 c}$ and Fructosamine Assays}

$\mathrm{HbA}_{1 \mathrm{c}}$ was determined using HPLC at the clinical laboratory of Louisiana State University Health Sciences Center-Shreveport. This assay is standardized according to the National Glycohemoglobin Standardization Program used for analysis. The fructosamine level was determined using a commercially available automated colorimetric nitroblue tetrazolium method [6].

\section{IL-8, MCP-1, Ketone Bodies and Oxidative Stress (Protein} Oxidation) Assays

IL-8 and MCP-1 levels were determined by the sandwich ELISA method using commercially available kits from Thermo Fisher Scientific Co. (Rockford, Ill., USA). All appropriate controls and standards as specified in the manufacturer's kit were used. During the cytokine assays, control samples were analyzed each time to check the variation from plate to plate on different days of analysis. The protein oxidation was assessed by determining the protein carbonyl levels in the plasma using an ELISA kit from Enzo Life Sciences International Inc. (Plymouth Meeting, Pa., USA). The concentrations of AA and BHB in plasma were determined as described previously [5]. The viability of cells in cell culture experiments was determined using the Alamar Blue reduction bioassay (Alamar Biosciences, Sacramento, Calif., USA). This method is based upon Alamar Blue dye reduction by live cells. All chemicals were purchased from Sigma Chemical Co. (St. Louis, Mo., USA) unless otherwise mentioned. Data were analyzed statistically using one-way analysis of variance among different groups using Sigma Stat and Sigma Plot software (Jandel Scientific, San Rafael, Calif., USA). A p value of less than 0.05 was considered significant.

\section{Results}

Table 1 gives the maternal age and fructosamine and $\mathrm{HbA}_{\mathrm{lc}}$ levels, as well as the birth weight, gestational age and length of hospital stay of the newborns. Maternal age in the two groups was similar. Although IDMs were larger than normal infants, the difference in their birth weights was not statistically significant. However, IDMs 
had slightly shorter gestational ages compared to those of the normal infants. The $\mathrm{HbA}_{1 \mathrm{c}}$ and fructosamine levels of diabetic mothers were higher compared with those of healthy mothers $(\mathrm{p}<0.01)$. Apgar scores were similar in the two groups, and none of the infants had meconiumstained amniotic fluid. None of the mothers in the diabetes or control (healthy) groups had chorioamnionitis or a history of substance abuse. Sepsis was neither suspected nor diagnosed in the newborn infants. Amongst the infants born to diabetic mothers, 6 had hypoglycemia which resolved within a few hours, 5 had macrosomia and 3 had congenital malformations ( 1 cleft lip and palate, 1 hypospadias, 1 ear anomaly).

$\mathrm{AA}$ and BHB levels in IDMs and infants of healthy mothers are shown in table 2 . There was a significant increase in plasma AA levels in IDMs compared with those of infants born to healthy mothers. Total ketone levels were obtained by adding the concentrations of AA and $\mathrm{BHB}$. There was a significant correlation in levels of total ketones $(\mathrm{r}=0.50, \mathrm{p}=0.016)$ and $\mathrm{BHB}(0.49, \mathrm{p}=0.018)$ but not AA $(0.26, p=0.22)$ between the mothers and their respective infants' cord blood in the diabetic group. There was no relationship to any ketone levels between mothers and cord blood in the healthy group. Table 2 also gives MCP-1 and protein oxidation levels in IDMs and infants of healthy mothers. There was a significant increase in protein oxidation and MCP-1 levels in IDMs compared with infants born to healthy mothers $(\mathrm{p}<0.05)$. The level of MCP-1 correlated significantly with that of total ketone bodies $(\mathrm{r}=0.41, \mathrm{p}=0.05)$ and AA $(\mathrm{r}=0.51, \mathrm{p}=0.01)$. When data from cord blood of all diabetic patients was separated into type 1 diabetes versus gestational and type 2 diabetes groups, there was an increase in MCP-1 levels in cord blood of infants of type 1 diabetic mothers (713 $\pm 211 \mathrm{pg} / \mathrm{ml}$ ) versus cord blood of infants of normal mothers $(269 \pm 32 \mathrm{pg} / \mathrm{ml})$, but it was not significant $(\mathrm{p}=$ 0.097). The MCP-1 levels in cord blood of infants of mothers with gestational diabetes $(493 \pm 162 \mathrm{pg} / \mathrm{ml})$ was similar to those in infants of healthy mothers. No relationship with gestational age was seen with MCP-1 $(r=0.15$, $\mathrm{p}=0.50)$ in cord blood samples. Similarly, there was no relationship between blood MCP-1 levels and birth weight in this study ( $\mathrm{r}=0.14, \mathrm{p}=0.51)$. Thus, differences in gestational age or birth weight are unlikely to have any effect on changes in MCP-1. There was no relationship between MCP-1 levels and maternal fructosamine or $\mathrm{HbA}_{1 \mathrm{c}}$ levels at delivery. The increase in plasma levels of IL-8 in IDMs compared with infants of healthy mothers was not statistically significant (table 2).

Figure 1 illustrates that treatment of monocytes with AA resulted in a concentration-dependent increase in secretion of MCP-1, suggesting that AA can stimulate

Table 1. Age, $\mathrm{HbA}_{1 \mathrm{C}}$ and fructosamine levels of mothers, and infant's birth weight, gestational age and length of hospital stay

\begin{tabular}{lccl}
\hline & $\begin{array}{l}\text { IDMs } \\
(\mathrm{n}=23)\end{array}$ & $\begin{array}{l}\text { Infants of } \\
\text { healthy mothers } \\
(\mathrm{n}=13)\end{array}$ & $\mathrm{p}$ \\
& $26.8 \pm 1.3$ & $26.5 \pm 1.7$ & $\mathrm{NS}$ \\
Mother's age, years & $7.0 \pm 0.3$ & $5.6 \pm 0.1$ & 0.01 \\
Mother's HbA $1 \mathrm{C}, \%$ & $198 \pm 8$ & $166 \pm 3$ & 0.01 \\
Mother's fructosamine, mM & $3,737 \pm 118$ & $3,221 \pm 81$ & $\mathrm{NS}$ \\
Newborn birth weight, g & $37.6 \pm 0.2$ & $39.3 \pm 0.3$ & 0.05 \\
Gestational age, weeks & $3.9 \pm 0.5$ & $2.2 \pm 0.1$ & 0.02 \\
Newborn length of stay, days & & & \\
\hline
\end{tabular}

Data are given as means \pm SEM. NS $=$ Not significant.

Table 2. Plasma inflammatory markers and ketone levels in diabetic and healthy groups

\begin{tabular}{|c|c|c|c|c|c|c|}
\hline & $\begin{array}{l}\text { Diabetic } \\
\text { mothers } \\
(n=23)\end{array}$ & $\begin{array}{l}\text { Healthy } \\
\text { mothers } \\
(n=13)\end{array}$ & $\mathrm{p}$ & $\begin{array}{l}\text { IDMs } \\
(n=23)\end{array}$ & $\begin{array}{l}\text { Infants of } \\
\text { healthy mothers } \\
(n=13)\end{array}$ & $\mathrm{p}$ \\
\hline $\mathrm{IL}-8, \mathrm{pg} / \mathrm{ml}$ & $7.95 \pm 2.6$ & $9.65 \pm 2.2$ & NS & $13.84 \pm 3.04$ & $9.27 \pm 2.15$ & NS \\
\hline MCP-1, pg/ml & $277 \pm 51$ & $328 \pm 63$ & NS & $608.4 \pm 133.6$ & $269.4 \pm 32.1$ & 0.04 \\
\hline $\mathrm{AA}, \mathrm{mM}$ & $0.38 \pm 0.12$ & $0.33 \pm 0.12$ & NS & $0.31 \pm 0.06$ & $0.15 \pm 0.05$ & 0.048 \\
\hline $\mathrm{BHB}, \mathrm{mM}$ & $2.4 \pm 0.47$ & $1.38 \pm 0.41$ & NS & $1.68 \pm 0.28$ & $1.39 \pm 0.46$ & NS \\
\hline Total ketones, $\mathrm{mM}$ & $2.8 \pm 0.5$ & $1.71 \pm 0.52$ & NS & $1.99 \pm 0.33$ & $1.54 \pm 0.47$ & NS \\
\hline Protein carbonyl, $\mu \mathrm{g} / \mathrm{ml}$ & $0.38 \pm 0.07$ & $0.31 \pm 0.14$ & NS & $0.30 \pm 0.05$ & $0.16 \pm 0.04$ & 0.047 \\
\hline
\end{tabular}

Data are given as means \pm SEM. NS $=$ Not significant. 


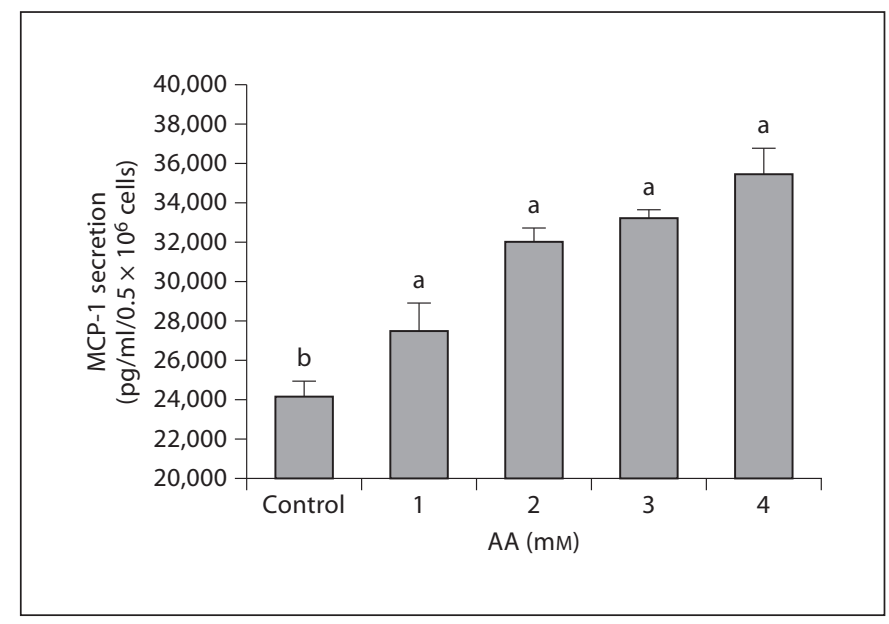

Fig. 1. The effect of AA on MCP-1 secretion in U937 monocytes. Values are means \pm SEM. ${ }^{b}$ versus ${ }^{a}$ is significant $(p<0.01)$.

MCP-1 secretion. In contrast, BHB treatment (1-5 $\mu \mathrm{M})$ did not show any effect on MCP-1 secretion (data not given here). Neither AA nor BHB treatment had an effect on cell viability (data not shown here). There was no change in $\mathrm{pH}$ of the culture medium after addition of AA. Air plus $\mathrm{CO}_{2}$ was used during cell culture incubation studies. The present study revealed AA levels in the range of $0.1-0.93 \mathrm{mM}$ in cord blood of IDMs and up to $1.96 \mathrm{mM}$ in the mother's blood. However, studies in the literature have reported more than $4 \mathrm{mM}$ AA levels in the blood of diabetic patients [13]. Thus, an AA concentration of $1 \mathrm{mM}$ is quite close to the physiological range. Our previous study showed an increase in MCP-1 after AA treatment of monocyte-rich human peripheral blood mononuclear cells isolated from human blood without activation with LPS [7]. Stimulation of monocytes with LPS has been used by many investigators for cell culture studies.

\section{Discussion}

Approximately 100,000 IDMs are born in the USA annually, some of whom may be at increased risk for metabolic and other complications [1]. The biochemical mechanisms leading to these complications are not completely understood. Recent studies suggest that hyperketonemia, oxidative stress and vascular inflammation may each play a role in the development of fetal complications during diabetic pregnancies. Ketone bodies can cross the placenta, and their levels have been found to be elevated in fetuses of diabetic mothers in pregnant ewes [12]. At birth, an increase in inflammatory markers such as C-reactive protein and intercellular adhesion molecule-1 has been reported in the offspring of type 1 diabetic mothers $[14,15]$. However, the effect of hyperketonemia on markers of vascular inflammation and oxidative stress in IDMs has not been investigated. For the first time, this study demonstrates increased levels of MCP-1 and protein oxidation in the cord blood of IDMs $(\mathrm{p}<0.05)$ but not in the cord blood of infants born to normal mothers. The level of MCP-1 correlated significantly $(\mathrm{p}=0.01)$ with the concentration of AA in the cord blood of IDMs. A significant correlation of MCP-1 with AA levels in the blood and increased secretion of MCP-1 in AA-treated monocytes suggests that hyperketonemia may contribute to elevated MCP-1 levels in IDMs.

MCP-1 is a chemokine secreted by different cell types [16]. It attracts monocytes into an area of inflammation and then activates them. Several studies have examined its role during normal and abnormal pregnancies and during the neonatal period $[17,18]$. Denison et al. [18] found that MCP-1 is important in the development of the placenta and thus maintaining a normal pregnancy. Briana et al. [19] estimated maternal and cord blood MCP-1 levels and reported significantly lower levels in growthretarded infants compared to healthy controls. MCP-1 levels are increased in women with type 1 and 2 diabetes $[20,21]$. Two separate studies from Poland reported that women with gestational diabetes showed increased levels of the chemokine MCP-1, possibly leading to adverse pregnancy outcomes $[22,23]$. The present study did not find a significant increase in the levels of IL- 8 in the cord blood of IDMs or the cord blood of infants born to normal mothers.

This study observed elevated levels of protein carbonyl, a marker of oxidative stress. The study by Kinalski et al. [24] in diabetic mothers suggests that their fetuses experience increased oxidative stress. The results show that AA, but not BHB, increased MCP-1 secretion in U937 monocytes exposed to high glucose. The reasons that one ketone body as opposed to the other affects inflammation differently remain unclear. We speculate that effects caused by AA may be due to the generation of oxygen radicals either directly or indirectly. It has been shown that $\mathrm{AA}$ but not $\mathrm{BHB}$ can generate oxygen radicals in a cell-free system [25-27], which may ultimately lead to an oxidative environment. It is also possible that AA is indirectly producing reactive oxygen species by 
being fed into the electron transport chain, creating an overload of electrons similar to that seen with hyperglycemia [25]. Since studies have also shown a decrease in the mitochondrial membrane potential in monocytes treated with AA, it seems likely that the mitochondria would be the second source of reactive oxygen species in monocytes treated with AA. Another possibility is that $\mathrm{AA}$ is converted to $\mathrm{BHB}$, which in turn can alter the redox state of the cell by affecting both nicotinamide adenine dinucleotide and glutathione levels. Structurally, the two compounds are very similar, but there is no ketone functional group present in $\mathrm{BHB}$. AA contains two keto groups whereas $\mathrm{BHB}$ does not, suggesting that the difference in chemical structure of the two ketone bodies may play a role in mediating the effects caused by AA and not BHB. AA is much less stable than BHB. Previous studies have also reported that the ketone body AA can increase oxygen radical formation and oxidative stress [25-27]. However, we found no correlation between levels of AA and protein oxidation levels in IDMs. The longterm outcomes of IDMs exposed to oxidative stress are unknown.

In conclusion, this study demonstrates that increases in circulating MCP-1 and protein oxidation levels in the cord blood of IDMs compared to normal infants suggest increased inflammation and oxidative stress. The hyper- glycemic environment reflected by higher $\mathrm{HbA}_{1 \mathrm{c}}$ and fructosamine levels in diabetic mothers and the presence of the AA ketone may be a factor in the increased MCP-1 levels in the cord blood of IDMs. The increase in oxidative stress may also result from elevated AA levels and/or glycosylation of antioxidative defense enzymes due to hyperglycemia. The role of elevated MCP-1 levels in the metabolic complications common to diabetic pregnancies needs further investigation in a larger patient population.

\section{Acknowledgements}

The authors thank Ms. Georgia Morgan for excellent editing of the manuscript. The authors are supported by grants from the National Institute of Diabetes and Digestive and Kidney Diseases, the Office of Dietary Supplements of the National Institutes of Health (RO1 DK072433) and the Malcolm Feist Endowed Chair in Diabetes.

\section{Disclosure Statement}

None of the authors has any financial interest in the publication of this paper, nor have they received any money from any sources other than the National Institutes of Health or Louisiana State University Health Sciences Center.

\section{References}

1 Yogev Y, Visser GH: Obesity, gestational diabetes and pregnancy outcome. Semin Fetal Neonatal Med 2009;14:77-84.

-2 Agoudemos M, Reinking BE, Koppenhafer SL, Segar JL, Scholz TD: Programming of adult cardiovascular disease following exposure to late-gestation hyperglycemia. Neonatology 2011;100:198-205.

3 Koskinen A, Laiho A, Lukkarinen H, Kaapa P: Maternal hyperglycemia modifies extracellular matrix signaling pathways in neonatal rat lung. Neonatology 2010;98:387-396.

-4 Newton CA, Raskin P: Diabetic ketoacidosis in type 1 and type 2 diabetes mellitus: clini$\mathrm{cal}$ and biochemical differences. Arch Intern Med 2004;164:1925-1931

-5 Jain SK, Kannan K, Lim G, Matthews-Greer J, McVie R, Bocchini JA Jr: Elevated blood interleukin-6 levels in hyperketonemic type 1 diabetic patients and secretion by acetoacetate-treated cultured U937 monocytes. Diabetes Care 2003;26:2139-2143.
6 Jain SK, Kannan K, Lim G, McVie R, Bocchini JA Jr: Hyperketonemia increases tumor necrosis factor-alpha secretion in cultured U937 monocytes and type 1 diabetic patients and is apparently mediated by oxidative stress and cAMP deficiency. Diabetes 2002;51:2287-2293.

7 Rains JL, Jain SK: Hyperketonemia increases monocyte adhesion to endothelial cells and is mediated by LFA-1 expression in monocytes and ICAM 1 expression in endothelial cells. Am J Physiol Endocrinol Metab 2011; 301:E298-E306.

8 Thornton NL, Cody MJ, Yost CC: Toll-like receptor $1 / 2$ stimulation induces elevated interleukin- 8 secretion in polymorphonuclear leukocytes isolated from preterm and term newborn infants. Neonatology 2012;101: 140-146.

-9 Verbruggen SC, Landzaat LJ, Reiss IKM, van Goudoever JB, Joosten KFM: Efficacy and safety of a tight glucose control protocol in critically ill term neonates. Neonatology 2012;101:232-238
10 Dahlgren J, Nilsson C, Jennische E, Ho HP, Eriksson E, Niklasson A, Björntorp P, Albertsson Wikland K, Holmäng A: Prenatal cytokine exposure results in obesity and gender-specific programming. Am J Physiol Endocrinol Metab 2001;281:E326-E334.

- 11 Rizzo T, Metzger BE, Burns WJ, Burns K: Correlations between antepartum maternal metabolism and child intelligence. N Engl J Med 1991;26;325:911-916.

12 Clark KE, Miodovnik M, Skillman CA, Mimouni F: Review of fetal cardiovascular and metabolic responses to diabetic insults in the pregnant ewe. Am J Perinatol 1998;5:312-318.

13 Candiloros HMS, Zeghari N, Donner M, Drouin P, Ziegler O: Decreased erythrocyte membrane fluidity in poorly controlled IDDM. Influence of ketone bodies. Diabetes Care 1995;18:549-551.

14 Nelson SM, Sattar N, Freeman DJ, Walker JD, Lindsay R: Inflammation and endothelial activation is evident at birth in offspring of mothers with type 1 diabetes. Diabetes 2007;56:2697-2704. 
15 Lindegaard ML, Svarrer EM, Damm P, Mathiesen ER, Nielsen LB: Increased LDL cholesterol and CRP in infants of mothers with type 1 diabetes. Diabetes Metab Res Rev 2008;24:465-471.

16 Yadav A, Saini V, Arora S: MCP-1: chemoattractant with a role beyond immunity: a review. Clin Chim Acta 2010;411:1570-1579.

-17 Takahashi N, Uehara R, Kobayashi M, Yada Y, Koike Y, Kawamata R, Odaka J, Honma Y, Momoi MY: Cytokine profiles of seventeen cytokines, growth factors and chemokines in cord blood and its relation to perinatal clinical findings. Cytokine 2010;49:331-337.

18 Denison FC, Kelly RW, Calder AA, Riley SC: Cytokine secretion by human fetal membranes, decidua and placenta at term. Hum Reprod 1998;13:3560-3565.

19 Briana DD, Boutsikou M, Baka S, Papadopoulos G, Gourgiotis D et. al.: Perinatal plasma monocyte chemotactic protein-1 concentrations in intrauterine growth restriction. Mediators Inflamm 2007;2007:65032.
0 Piemonti L, Calori G, Mercalli A, Lattuada G, Monti P, Garancini MP, Costantino F, Ruotolo G, Luzi L, Perseghin G: Fasting plasma leptin, tumor necrosis factor-alpha receptor 2 , and monocyte chemoattracting protein 1 concentration in a population of glucose-tolerant and glucose-intolerant women: impact on cardiovascular mortality. Diabetes Care 2003;26:2883-2889.

21 Nomura S, Shouzu A, Omoto S, Nishikawa M, Fukuhara S: Significance of chemokines and activated platelets in patients with diabetes. Clin Exp Immunol 2000;121:437-443.

22 Lappas M, Hiden U, Desoye G, Froehlich J, Hauguel-de Mouzon S, Jawerbaum A: The role of oxidative stress in the pathophysiology of gestational diabetes mellitus. Antioxid Redox Signal 2011;15:3061-3100.

23 Wender-Ozegowska E, Michalowska-Wender G, Zawiejska A, Pietryga M, Brazert J, Wender M: Concentration of chemokines in peripheral blood in first trimester of diabetic pregnancy. Acta Obstet Gynecol Scand 2008;87:14-19.
24 Kinalski M, Sledziewski A, Telejko B, Kowalska I, Kretowski A, Zarzycki W, Kinalska I: Lipid peroxidation, antioxidant defence and acid-base status in cord blood at birth: the influence of diabetes. Horm Metab Res 2001;33:227-231

25 Rains JL, Jain SK: Oxidative stress, insulin signaling, and diabetes. Free Radic Biol Med 2011;50:567-575.

26 Jain SK, McVie R: Hyperketonemia can increase lipid peroxidation and lower glutathione levels in human erythrocytes in vitro and in type 1 diabetic patients. Diabetes 1999;48:1850-1855.

27 Jain SK, Kannan K, Lim G: Ketosis (acetoacetate) can generate oxygen radicals and cause increased lipid peroxidation and growth inhibition in human endothelial cells. Free Radic Biol Med 1998;25:1083-1088. 